\title{
NOCIONES, CREENCIAS E IDEAS SOBRE PLAGAS DE LANGOSTA EN GUATEMALA Y NUEVA ESPAÑA, SIGLO XVIII*
}

\author{
LUis AlBerto ARrioja DíAZ Viruell \\ El Colegio de Michoacán, México \\ larrioja@colmich.edu.mx
}

\section{Resumen}

Este artículo analiza la manera en que las autoridades - políticas y religiosas- de dos espacios indianos -la capitanía mayor de Guatemala y el virreinato de Nueva Españapercibieron y entendieron las plagas de langosta entre 1700 y 1805; asimismo, se analizan una serie de instrumentos -temporales y espirituales- que ponen de relieve las nociones e ideas que existían sobre dichos fenómenos. A lo largo del texto se examina el contexto -ideológico y fáctico- en que surgieron y evolucionaron dichas ideas. Primeramente, aquellas que se basaron en argumentos bíblicos y providencialistas. En segundo lugar, las que se anclaron en el pensamiento racionalista e ilustrado.

Palabras clave: Plagas de langosta; Amenaza natural; Ideas providencialistas;

Pensamiento naturalista; Pulsación climática; Guatemala; Nueva España.

\section{Abstract}

Notions, beliefs and ideas about locust plagues in Guatemala and New Spain, XVIII Century

This article analyzes the way in which the political and religious authorities of Guatemala and New Spain perceived and understood the locust plagues in XVIII Century.

* Este artículo forma parte del proyecto de investigación intitulado «México y Guatemala: historia de tres plagas de langosta y el estudio de su impacto ambiental y social (siglos XVIII y XIX)», apoyado por el Consejo Nacional de Ciencia y Tecnología (registro CB-222118). 
It studies a numerous of instruments that highlight the notions and ideas about these natural phenomenon. At the same time, this article examine the context-ideological and factual - in which these ideas emerged and evolved. First, those based on biblical arguments. Second, those that were anchored in rationalist and illustrated thinking.

Keywords: Locust plagues; Natural threats; Providentialist ideas; Naturalist thinking; Climatic pulsation; Guatemala; New Spain.

\section{Introducción}

Hablar de plagas de langosta en los territorios de la América española implica aludir la existencia de un fenómeno natural que fue recurrente, perspicaz, azaroso, destructivo e intimidador. Asimismo, conlleva hablar de una amenaza biológica que lo mismo fue interpretada desde la óptica del providencialismo que desde el racionalismo. Dado esto, no es casualidad que la historiografía especializada utilice el concepto de plaga para referir la presencia de una comunidad de insectos que actúa sobre las especies vegetales de un territorio causando daños irreversibles en cadenas tróficas y ecosistemas. Inclusive, dicho vocablo también se ha empleado para ilustrar la manera en que las sociedades de antiguo régimen sufrían el deterioro de sus campos al tiempo en que los enjambres de insectos se posicionaban en ellos y los devastaban. No obstante, examinando una serie de documentos elaborados por la monarquía hispana, salta a la vista que dichas expresiones -plagas y langostas-sirvieron para referir dos componentes estrechamente articulados con sociedades campesinas, actividades agrícolas, ideas religiosas, preceptos de la naturaleza y -en su momento- reflexiones científicas. En este sentido, debo subrayar que tanto las ideas providencialistas como ilustradas fueron determinantes para definir los contenidos y contextos de estos vocablos. De ahí que sus acepciones refieran -primero- pasajes bíblicos e ideas propias de la escolástica, y -posteriormente-argumentos fundamentados en la biología, el clima y la salud pública. ${ }^{1}$ Este artículo tiene el objeto de examinar la manera en que las autoridades -políticas y religiosas- de dos espacios indianos -la capitanía mayor de Guatemala y el virreinato de Nueva España- percibieron

1. Para ampliar estas ideas, véase TrabUlSE, 2010:15-42. GruZinSKI, 2000: 62-65. CAÑIZARES ESGUERRA, 2008. 
y entendieron las plagas de langosta entre 1700 y 1805; asimismo, se analizan una serie de instrumentos -temporales y espirituales- que ponen de relieve la noción que se tenía sobre dichos fenómenos. En este ejercicio, examino el contexto en que surgieron y evolucionaron estas ideas. Primeramente, aquellas que se basaron en argumentos bíblicos y providencialistas. En segundo lugar, las que se anclaron en el pensamiento racionalista e ilustrado. Debo subrayar que este enfoque analítico no tiene otro interés más que examinar una serie de materiales que comparten ideas, discursos y esquemas. De esta manera, el lector podrá observar la forma en que algunas perspectivas ilustradas fueron inspiradas por conocimientos del mundo escolástico, y-sobre todo- vislumbrar cómo ciertas nociones providencialistas se mantuvieron vigentes y plenas durante la ilustración.

\section{El insecto prohibido, profano y apocalíptico}

A juzgar por Claude Lévi-Strauss, Marvin Harris y Michel Pastoureau, las percepciones que los humanos han construido sobre ciertos animales a lo largo del tiempo se distinguen por aglutinar creencias, fobias, traumas y numerosas ambivalencias. Para unas especies, la capacidad de adaptarse al medio y el sitio que ocupan en las cadenas alimenticias les ha permitido ubicarse en los mejores pasajes de la historia; para otras, las construcciones simbólicas que pesan sobre ellas las posicionan en escenarios marginales. Sin duda, las ideas heredadas de las religiones monoteístas y los mitos transmitidos por los grupos primitivos han jugado un papel decisivo en la construcción de estos enfoques, al grado de borrar las virtudes de algunas especies y -en algunos casos- exaltar los aspectos negativos. ${ }^{2}$ Prueba de ello han sido las langostas; insectos del orden Ortópteros, del género Shistocerca, que a juzgar por la entomología han proliferado -históricamente- por todo el globo terráqueo, contribuido a la formación de ecosistemas complejos e inclusive han formado parte de los complementos alimenticios de ciertas civilizaciones. ${ }^{3}$ No obstante, se sabe que -desde la antigüedad-algunos pueblos de Medio Oriente y Europa Central gestaron una serie de discursos y restricciones sobre dicha

2. LÉVI-STRAUSS, 1986: 34-45; 1988: 22-25. HARRIS, 1989: 202-230. PASTOUREAU, 2015: 55-57.

3. SISTACH, 2007. 
especie. Hasta donde puede observarse, las restricciones se desprendieron de una vieja doctrina maniquea que compendiaba los llamados tres sellos: boca, manos y senos. En el caso específico de la boca, la doctrina prohibió introducir en ella las cosas impuras, las especies que estaban ausentes de principios divinos, la carne de animales que devoraban carroña y basura, y todo aquello que la ensuciaba. ${ }^{4}$ Examinando esta perspectiva desde algunas religiones monoteístas, salta a la vista que la langosta fue un insecto proscrito para el judaísmo, especialmente cuando los bichos alcanzaron su condición migratoria. Dado esto, la ley mosaica precisó que todo insecto alado era inmundo. Sin duda, las razones esgrimidas por las leyes de Moisés se anclaron en el orden simbólico; es decir, se percibió a la langosta -en su condición de larva y saltón- como una especie inofensiva y como un recurso alimenticio, pues -según el Levítico- el profeta Juan sobrevivió al desierto comiendo estos bichos. No obstante, cuando la especie desarrolló alas, transformó su conducta gregaria y devoró los cultivos existentes, el judaísmo la etiquetó como un animal impuro y peligroso. De hecho, esta apreciación quedo plasmada en las interpretaciones del profeta Joel al tiempo en que una plaga devastó por más de un año las tierras de Judá. Desde la óptica del profeta, la plaga fue una advertencia para que los hebreos regresaran a Dios «de todo corazón, con el ayuno, los llantos y los lamentos...». Para algunos antropólogos, la relación entre Dios y la naturaleza fue una forma simbólica en que el pueblo hebreo ponderó el comportamiento espiritual de los hombres: la tierra era fértil y próspera en tiempos de comunión y obediencia, y estéril y amenazada en épocas de deslealtad y mentira. ${ }^{5}$

En lo que respecta a las posturas cristianas, puede decirse que se fundamentaron en la tradición bíblica y tuvieron que ver con las ideas planteadas en el Libro de los proverbios y el Libro del Éxodo. En el primero de ellos, el rey Salomón -monarca supremo de Israel-advirtió que la langosta era un insecto impuro por naturaleza, ya que «no tiene rey... y avanza en escuadrones... que causan la muerte...»; además, era considerada una amenaza legítima para los pueblos y se vislumbraba como una prueba de la más fehaciente decadencia. En el Éxodo, la langosta apareció con la misma carga simbólica. A lo largo de

4. LORA, 2013: 54.

5. LÉVI-STRAUSS, 1988: 141-143. GÉRARD y NORDON GÉRARD, 1996. 
sus páginas, se presentó al ortóptero como una especie que generaba daños en las comunidades vegetales y humanas, y permanecía largo tiempo en los territorios que infestaba. Prueba de ello fue el mensaje que Yahvé remitió al faraón en caso de que no liberara a los israelitas: «le enviaré la langosta sobre su territorio, la cual cubrirá toda la tierra y no verá nada en ella; y se comerá todos los árboles y todos los granos que se hayan podido guardar, y entrará en todas las casas de sus servidores...» Otra apreciación se encuentra en el contexto del Apocalipsis y -específicamente- de la octava plaga; una plaga que castigó al faraón por desafiar la palabra de Yahvé, por esclavizar al pueblo judío y por desatender los mandamientos divinos. Dado esto, el texto refiere que: «las langostas subieron por toda la tierra de Egipto, y eran tantas que se oscureció el día... Se comieron toda la hierba de la tierra, todos los frutos de los árboles..., y no quedo nada verde...» Al igual que en el judaísmo, esta apreciación se cimentó en un entramado simbólico donde el animal era definido en un contexto donde predominaba la catástrofe, el hambre y la enfermedad. ${ }^{6}$

Todo parece indicar que desde el origen de estas religiones monoteístas (judaísmo y cristianismo) se configuraron apreciaciones negativas sobre ciertas especies animales, sobresaliendo el caso de la langosta, el cerdo y la serpiente. Lo anterior tuvo que ver con un horizonte donde los jerarcas religiosos pretendieron - a cada momento- regular la realidad de sus feligreses por medio de reglas, mitos, tabúes o leyendas; asimismo, mantener un equilibrio entre la población y los recursos existentes en sus territorios. Sobre esto último, Claude Lévi-Strauss y Marvin Harris advierten que no fue casualidad que estas nociones se conformaran en épocas y escenarios donde era evidente el conflicto entre una población densa -como la que abarrotaba Egipto-y un territorio desprovisto de recursos alimenticios. Inclusive, dichas perspectivas evidenciaron que -en épocas de escasez- los hombres y los animales competían por la subsistencia. ${ }^{7}$

Es de advertir que estos enfoques sobre la langosta se enriquecieron y difundieron con el paso del tiempo. En la época clásica, las opiniones de Aristóteles, Teofrasto, Eliano y Plinio se encargaron de validar los aspectos

6. HARRIS, 1989: 216.

7. LÉVI-STRAUSS, 1988: 141-143. HARRIS, 1989: 216.

Revista de Historia Moderna, n. ${ }^{\circ} 35$ (2017) (pp. 214-253) | ISSN-e: 1989-9823 | ISSN: 0212-5862 
«nocivos» e «impuros» del animal, ratificaron los daños que causaba sobre la cubierta vegetal y proyectaron imágenes parias sobre su condición migratoria; una condición que -desde su perspectiva- respondía a conductas fundadas en la maldad, el daño y el castigo divino: «Tiene proceder de la ira de Dios esta pestilencia, porque se ven muy grandes y vuelan con tan grande ruido de sus alas que se cree ser aves mayores y quitan el sol, mirando los pueblos con grande congoja no les cubran sus tierras, porque tienen fuerzas bastantes... y cubren con nube cruel las mieses, quemando gran parte de ellas con su toque...» ${ }^{8}$

A juzgar por Xavier Sistach, estos discursos fueron enriquecidos durante la Edad Media y el Renacimiento. En el caso específico de Europa occidental, el vehículo precursor de estas nociones fue la religión cristiana a través de numerosos manuscritos que se tradujeron a lenguas romances. Prueba de ello fueron las opiniones vertidas en los textos de Honoré de Autun (1150), Alexander Neckham (1160), Vincent de Beauvais (1250), Thomas de Cantimpré (1270), Thomas Mouffet (1589) y María Sibylla Merian (1705). ${ }^{9}$ Además de estas obras, la presencia física de la langosta en varios confines sirvió de precedente para definir un imaginario cimentado en lo abominable, apoteósico y demoniaco. Tan solo, entre 1400 y 1750, estos bichos afectaron regiones extensas de Alemania, España, Francia Italia, Polonia, Portugal, Rusia y Turquía. ${ }^{10}$ Inclusive, la apreciación de estas plagas no solo se registró en los manuscritos oficiales, sino también en textos y obras pictóricas que evidenciaron las afectaciones agrícolas y -sobre todo- validaron la retórica providencialista de amenazas, infortunios y desgracias. Sobre esto último, destacan los dibujos y comentarios de Ruperto de Deutz sobre el Apocalipsis (1116), las visiones del profeta Joel en la Biblia Monumental de Admont (1150), los grabados sobre estos insectos en el Liber chronicarum mundi (1493), las ilustraciones sobre el Éxodo en la Biblia Lübeck (1494) y los impresos sobre el Apocalipsis en la Biblia de Martín Lutero $(1534)^{11}$. A lo anterior se sumaron

8. Plinio, «De los pequeños animales y que rastrean», en SISTACH, 2007.

9. HARRIS, 1989: 229.

10. Una visión panorámica sobre las plagas de langosta en Europa, puede encontrarse en CAMufFo, D. y EnZI, 43 (1991): 43-73 y White, 2011.

11. Una muestra de estos ejemplares puede consultarse en FüSSEL, GASTGEBER y Fingernagel, 2016. Spencer Collection, The New York Public Library, «Exodus 
varias obras pictóricas alusivas a dichas amenazas, tales como el «Descenso de la virgen para aliviar la plaga de langosta» (1718) de autor anónimo (ubicado en el convento de Nuestra Señora de la Merced de Lleida, España), el «San Agustín conjurando una plaga de langosta» (1734) de Miguel Jacinto Meléndez (ubicado en el convento agustino de San Felipe del Real de Madrid, España) y los numerosos detalles y frescos del retablo de la Virgen de la langosta (1674) (localizado en la ermita de Alpeñes, España). Por si esto no fuera suficiente, aparecieron numerosos manuscritos que condenaron las conductas de estos insectos, legitimaron sus antecedentes bíblicos y validaron los temores que provocaban entre la población. Prueba de ello son las notas aparecidas en diccionarios, diarios, gacetas y panfletos que circularon en la monarquía hispana. En 1734, por ejemplo, el Diccionario de la lengua castellana... definió estos acrídidos como «insectos que tienen la cabeza como buey, el hocico romo y ancho, la boca cuadrada, los ojos saltados y los cuernos movibles. Tiene cuatro alas, unas sobre otras, seis pies, los cuatro anteriores pequeños y los dos de atrás muy largos y acomodados para saltar... Luego que se pone el sol se abaten a la tierra, haciendo un estrago horrible en los trigos, plantas y semillas. Es plaga con que castiga Dios los pecados de los hombres, y regularmente dura siete años...» ${ }^{12}$

El Mercurio histórico y político..., por su parte, publicó que -en las costas mediterráneas- las plagas de langosta eran recurrentes y se distinguían por cubrir el horizonte por varios días hasta colapsarse -repentinamente- sobre los campos y devastarlos; asimismo, advertía que en la antigua Anatolia «el número de estos insectos es tan prodigioso, que obscurecen el Sol cuando se levantan para volar de un paraje a otro. Los habitantes están consternados por verse amenazados de una hambre general, que será difícil precaver... ${ }^{13}$

[Plague of locusts.]» The New York Public Library Digital Collections. 1494. https:// digitalcollections.nypl.org/items/89b685df-6e21-488b-e040-e00al8066f61

12. Diccionario de la lengua castellana, 1734, T. IV: 358.

13. Mercurio histórico y político que contiene el estado presente de la Europa, lo sucedido en todas las Cortes, los intereses de los Príncipes, y generalmente lo más curioso, perteneciente al mes de junio de 1757, Madrid, Imprenta de Antonio Marín, 1757: 18. Disponible en: http://hemerotecadigital.bne.es/issue.vm?id=0012183457\&search=\&lang=es; Mercurio histórico y político que contiene el estado presente de la Europa, lo sucedido en todas las Cortes, los intereses de los Príncipes, y generalmente lo más curioso, perteneciente al mes 
Inclusive, el mismo Diccionario de la lengua castellana... definió las plagas como «calamidades grandes que ordinariamente manda Dios a las provincias, reinos o lugares, en castigo y pena de sus culpas. Como la langosta...» En este mismo orden, varios pensadores de la época dedicaron algunas páginas al insecto y los estragos que causaba en el mundo terrenal, tales como Gaspar Melchor de Jovellanos, Francisco Cabarrús, Jean Baptiste Lamarck, George Cuvier, Charles Linneo y Georges Louis Leclerc (conde de Buffon). Este último, por ejemplo, anotó que el acrídido era inofensivo y pacifico en su estado embrionario, pero resultaba una especie hostil, mutante y devastadora en su edad adulta. Inclusive, señaló que, pese a las creencias sobre su consumo, se trataba de una «especie maldita y prohibida para los seres humanos...» $\mathrm{Al}$ respecto, anotó que:

En las fronteras de los desiertos de Etiopia habita un pueblo que llaman de los Acridóphagos o comedores de langostas. Sus individuos son negros, flacos, muy ligeros en la carrera y de pequeña estatura. No crían ganado ni cogen pesca y así están reducidos a vivir de las langostas que en cantidad numerosísima traen a su país en la primavera ciertos vientos cálidos de occidente, y de que ellos juntan copia considerable que polvorean con sal y guardan para irse manteniendo todo el año. Este perjudicial alimento produce en ellos los dos raros efectos, de que su vida apenas llegue a cuarenta años, y de que cuando se acercan a esta edad se engendre en sus carnes una multitud de insectos alados, que empezando por comerles el vientre, les devoran después el pecho y en fin les roen hasta los huesos. ${ }^{14}$

Si se toman en cuenta los elementos expuestos, no es de extrañar que los cronistas, oficiales y religiosos de Indias repitieran - una y otra vez- estas y otras perspectivas sobre las plagas de insectos e inclusive las adecuaran en función de sus intereses. Es de advertir que dichas nociones se plasmaron a la luz de un horizonte dominado por la tradición bíblica: la plaga de Egipto y los caballeros del Apocalipsis; incluso, como ha señalado Jorge Cañizares Esguerra, buena parte de estos cronistas se sintieron acorralados por dicha tradición y llegaron a considerar que el tiempo atmosférico, las plantas, los animales y los paisajes del Nuevo Mundo eran controlados por Satanás; de

de septiembre de 1778, Madrid, Imprenta Real de la Gazeta, 1778: 10-11. Disponible en: http://hemerotecadigital.bne.es/issue.vm?id=0012208981\&search=\&lang=es 14. BUFFON, 1798: 230. 
ahí, entonces, que las visiones bíblicas y demonológicas animaran las percepciones de la naturaleza americana. ${ }^{15}$ En este orden, sobresalen varios textos que revelan las nociones que se difundieron sobre estos ortópteros en Nueva España y Guatemala. Uno de ellos es la Historia verdadera de las cosas de Nueva España... (1575) de Bernal Díaz del Castillo, obra donde las plagas aparecen referidas en las tierras mayas de Champotón y donde los insectos forman parte de un horizonte marcado por la guerra, el hambre y la enfermedad, y donde su comportamiento es descrito como pernicioso para los conquistadores y los grupos nativos: «las langostas invadieron todos los campos de guerra..., al grado que cuando peleábamos saltaban y venían volando y nos daban en la cara, y como eran muchos los indios flecheros y tiraban tanta flecha como granizos, nos parecían que eran algunas de ellas langostas y que volaban, y no nos rodelabamos, y la flecha que venía y nos hería; otras veces, creíamos que eran flechas y eran langostas que venían volando, fue harto estorbo para nuestro pelear...» ${ }^{16}$

Entretanto, fray Diego de Landa señaló en su Relación de las cosas de Yucatán... (1566) que, al tiempo en que los pueblos nativos enfrentaron la dominación militar española, se «recreció la langosta por espacio de cinco años, que no les dejaba cosa verde; y vinieron a tanta hambre que se caían de muertos por los caminos, de manera que cuando los españoles volvieron no conocían la tierra aunque con otros cuatro años buenos después de la langosta, se había mejorado algo... ${ }^{17}$ Años después, fray Jerónimo de Mendieta reveló en la Historia eclesiástica indiana... (1590) que la conquista y dominación española fue entendida - «según la relación y pintura de los viejos indígenas...»- como un entramado de infortunios «propios del Apocalipsis...», pues previo a la conquista militar, estos pueblos sufrieron "guerras continuas... y el haber venido un año gran cantidad de langostas, y otro haber nevado mucho por toda la comarca de México (cosa que jamás suele acontecer) y otras cosas así semejantes...», que sirvieron de precedente para mermar la conducta bélica de los pueblos y sucumbir ante el embate de las huestes

15. CAÑIZARES ESGUERRA, 2008: 54-55.

16. DíAZ DEL CASTILlO, 1960: cap. IX.

17. LANDA, 1938: 29.

Revista de Historia Moderna, n. ${ }^{\circ} 35$ (2017) (pp. 214-253) | ISSN-e: 1989-9823 | ISSN: 0212-5862 
españolas. ${ }^{18}$ Siguiendo las mismas ideas, el padre Joseph de Acosta anotó en la Historia natural y moral de las Indias... (1590) que estas plagas eran «un castigo divino... donde animales crecidos en número y en grandeza... se comen todo a su paso y andan por los campos causando daños...» ${ }^{19}$

Las obras de fray Bernardino de Sahagún -para Nueva España- y fray Thomas de Coto - para Guatemala-, ponen de manifiesto que si bien durante el siglo XVI se preservaron algunas nociones precolombinas sobre estas plagas, también es verdad que el desarrollo de la colonización y el avance de las ideas cristianas mermaron estas perspectivas y provocaron su ocultación, al grado que -durante el siglo XVII- las apreciaciones se plantearon bajo el influjo del antiguo testamento. ${ }^{20}$ No obstante, como refieren Gruzinski y Cañizares, estos testimonios también deben leerse como una forma cristiana de entender los comportamientos de la naturaleza en las Indias; comportamientos que -en su aspecto más evidente- se interpretaron bajo una retórica donde la naturaleza del Nuevo Mundo fue entendida -hasta cierto punto- como una amenaza constante. $^{21}$

Conviene advertir que esta perspectiva fue tan influyente que, inclusive, algunas obras de manufactura indígena adecuaron y reprodujeron dicho discurso. Si bien es cierto que estos hechos deben explicarse a la luz de los procesos de evangelización, también es verdad que deben reflexionarse como elementos que coadyuvaron la formación y propagación de ideas occidentales en el seno de las poblaciones nativas. Una prueba de ello se desprende del Chilam Balam de Chumayel, obra que documenta los procesos de conquista en el área maya desde una perspectiva nativa, pero bajo influjos del pensamiento cristiano. Un análisis del manuscrito pone de relieve que los mayas peninsulares refirieron la conquista como un proceso de muerte, desolación y hambre que iba acompañado de fenómenos naturales que afectaban a la población en general. De ahí que no escatimaran en referir que: «...estos hombres de Dios, doblando su espalda sobre la tierra virgen, manifestaron la carga de las penas, en presencia de Dios Nuestro padre, para cuando venga

18. MENDIETA, 1890: 172.

19. Acosta, 2006: 222.

20. SAHAGÚn, 1992: 658. COTO y ACUÑa, 1983: 187, 305.

21. GRUZINSKI, 2000: 69-70; CAÑIZARES ESGUERRA, 2008: 55.

Revista de Historia Moderna, n. ${ }^{\circ} 35$ (2017) (pp. 214-253) | ISSN-e: 1989-9823 | ISSN: 0212-5862 
a entrar el cristianismo... habrá vómitos de sangre, pestes, sequías, años de langosta, viruelas, la carga de la miseria, el pleito del diablo... también bajarán hormigas como tigres... vendrán años de langosta... Tres veces colgaran su estrechez. Tres veces se morirán las hojas...» $»^{22}$ Otra muestra de las ideas providencialistas puede observarse en el Memorial de Sololá, una obra del siglo XVII que versa sobre los anales del pueblo Quiché. Al igual que el Chilam Balam, el Memorial presenta los primeros años de la dominación española como una etapa marcada por hechos bélicos y situaciones naturales adversas: «Cien días después de haber salido las palomas del bosque, llegó la langosta... El día 2 Yq [30 de junio de 1513] pasó por la ciudad y en verdad causó gran alarma en aquel tiempo antiguo el paso de la langosta... ${ }^{23}$

Cabe señalar que estos ejemplos sobre la adversidad de los insectos también se reprodujeron en varias crónicas del siglo XVII. En el caso novohispano, sobresalen los registros de fray Juan de Torquemada (1612), fray Juan de Grijalva (1624) ${ }^{24}$ y fray Francisco de Burgoa (1670). Torquemada, por ejemplo, señaló en su Monarquía indiana... que las plagas de langosta eran resultado de la ira divina y debían entenderse como una respuesta a las conductas pecaminosas, prohibidas y distantes de la espiritualidad en que vivían los indios y españoles, de ahí que todos los «hombres paganos e impuros... destruyan y abracen todo por donde pasan, como lo hace la langosta... $»^{25}$ Grijalva, por su parte, reconoció estas plagas en la Crónica de la Orden de Nuestra Padre San Agustín... y las describió como «un flagelo que talaba los campos hasta las mieses...» y que la única forma de combatirlas era realizando misas, promesas, rogativas y arrepentimientos públicos, pues la única razón que explicaba su origen se encontraba en la conducta humana. ${ }^{26}$ Entretanto, Burgoa advirtió en la Palestra historial... que las plagas experimentadas en la provincia de Oaxaca «a la letra se deben entender como el daño tan sensible que causa esta sabandija voraz, como de ordinario a pocos años experimentamos en las Indias, que cubren la media región y hacen sombra a la luz del sol por donde pasan talando plantas y árboles donde se alojan...»; inclusive,

22. Mediz Bolio, 1930: 85, 93.

23. ReCinOS, 2006: 118-119. García QuiNTANILLA, 16 (2005): 327-344.

24. GRIJALVA, 1624: 191.

25. MENDIETA, 1890: 172; TORQUEMADA 1723: 24.

26. GRIJALVA, 1624: 119 .

Revista de Historia Moderna, n. ${ }^{\circ} 35$ (2017) (pp. 214-253) | ISSN-e: 1989-9823 | ISSN: 0212-5862 
desde su óptica, las plagas eran resultado de la idolatría que practicaban los pueblos «y de los estragos de la culpa, que es la única enemiga de la fe y que de los vicios el que consume y acaba la vida del alma y frutos del espíritu santo, pues niega el ser infinito, eterno e indivisible de Dios...; de ahí tanto castigo en estas tierras... ${ }^{27}$

En lo que respecta a Guatemala, varios religiosos y oficiales reales documentaron acuciosamente la presencia y los estragos que causaba estos ortópteros, tal es el caso de fray Antonio de Remesal (1619) ${ }^{28}$, Thomas Gage (1649) ${ }^{29}$, Francisco Antonio de Fuentes y Guzmán $(1690)^{30}$ y fray Francisco Vázquez $(1716)^{31}$. Entre los relatos más precisos y extensos, sobresale el de Thomas Gage, quien advirtió que al visitar los pueblos del altiplano guatemalteco fue testigo de una plaga de gran magnitud:

En el primer año que yo viví allí, Dios envió una de las siete plagas de Egipto que jamás había visto, una plaga de langosta... Estas langostas eran parecidas a las de Europa, pero más gordas, y volaban todas unidas por bandadas y en tan gran número, que oscurecían el día impidiendo el paso de los rayos del sol. Por todas las partes donde se pegaban no se veía otra cosa más que señales de ruinas y desolación; porque no solamente comían los trigos sino también las hojas y frutas de los árboles, a donde acudían en tan gran número que, con su peso, rompían las ramas donde se paraban y las separaban del tronco del árbol. Los grandes caminos estaban todos cubiertos, de suerte que ellas hacian temblar a cada instante las mulas que andaban por el país, silbando alrededor de sus orejas y cosquillándoles los píes. Yo me acuerdo que caminando en el país estaba tan molesto por estos animales que si no hubiera tenido puesta una máscara con anteojos, me hubiera sido imposible poder continuar mi camino. Los rancheros que habitaban hacia la costa del sur se quejaban de que su añil, que aún no era maduro, estaba a punto de ser destruido por estas langostas. Los que cultivaban la azúcar se quejaban también de sus cañas, que aún estaban tiernas, corrían el mismo peligro; pero sobretodo era una cosa digna de lástima oír las quejas de ellos labradores del valle donde yo vivía, quienes temían que su trigo fuera devorado en una noche por este ejército de langostas. ${ }^{32}$

27. BURGOA, 1989: 220-221.

28. REMESAL, 1619: 170, 347.

29. GAGE, 2000: 35-38.

30. FUENTES Y GUZMÁN, 1882.

31. VÁZQUEZ, 1940: 28-29.

32. GAGE, 2000: 37-38. 
Relatos muy semejantes quedaron plasmados en cuadros, grabados, murales y retablos que, sin duda, coadyuvaron en la consolidación del imaginario providencial. Siguiendo a Gruzinski, estas versiones ofrecieron al conquistador una serie de herramientas para transmitir un imaginario sobre los fenómenos naturales y su comportamiento extremo; asimismo, proporcionaron argumentos para relacionar las conductas mundanas, la naturaleza transgredida y la ira de Dios. Prueba de ello son los frescos sobre el Apocalipsis -de Juan Gersonque adornan la iglesia de San Francisco de Asís en Tecamachalco, Puebla, así como las pinturas sobre la huida de Egipto que cubren las bóvedas de la iglesia de San Miguel Arcángel en Ixmiquilpán, Guerrero ${ }^{33}$; imágenes que, de una $\mathrm{u}$ otra forma, se utilizaron para construir, legitimar y difundir la perspectiva apocalíptica y demoniaca sobre las plagas de langosta en territorios indianos.

\section{De plagas bíblicas a amenazas naturales}

Existe un consenso amplio en la historiografía dedicada a la monarquía hispana sobre las vías que posibilitaron la propagación de ideas, perspectivas, creencias y valores durante los siglos XVII y XVIII. Hasta donde puede observarse, tanto la palabra escrita como el discurso público fueron los canales de mayor influencia y difusión. A juzgar por Fernando Bouza, el recurso de la escritura fue indispensable tanto para gobernar los escenarios de la monarquía como para hacerse presente en ella, y-sobre todo para difundir ideas, recabar posturas y promover acciones ${ }^{34} \mathrm{~A}$ lo anterior habrá que sumar la posibilidad de la monarquía de configurar perspectivas o formas de ver y entender el mundo natural, sus complejidades, significados y riesgos. Centrando la atención en las experiencias de Guatemala y Nueva España, bien puede decirse que un horizonte para comprender las nociones existentes sobre las plagas de langosta se ubica en los documentos redactados por los ministros de la iglesia y los oficiales reales al tiempo en que dichas amenazas afectaban sus territorios y trastornaban la vida terrenal; textos que lo mismo procedían de la península y los dominios americanos, que respondían a circunstancias específicas y extraordinarias, que se plasmaban a la luz de necesidades terrenales o espirituales y que -muchas veces- revelaban traumas y miedos aprendidos. Si

33. GRUZINSKI, 1994: 148-171. GÓMEZ, Lidia, 2006: 89-106.

34. BOUZA, 2001: 21-22; 1999; 2008: 20-21. BuRNS, 2010. MUNCK, 2001: 115-116.

Revista de Historia Moderna, n. ${ }^{\circ} 35$ (2017) (pp. 214-253) | ISSN-e: 1989-9823 | ISSN: 0212-5862 
bien resulta difícil determinar el influjo que tuvieron estos materiales, lo cierto es que su presencia en el ámbito regional representó una pieza fundamental en los procesos de comunicación y difusión de ideas. Dada su naturaleza, estas fuentes se plasmaron en los formatos más tradicionales del mundo temporal (tratados, proyectos, folletos, gacetas, reportes, reseñas, noticias, órdenes, cédulas, bandos, cordilleras y opúsculos) y espiritual (textos devocionales, sermones, exorcismos, conjuros, rogativas y súplicas). Sin duda, su circulación pone de relieve la postura de las instituciones en tiempos de contingencia, el papel de las autoridades en la propagación de ideas y el peso de la palabra escrita en la configuración de nociones y perspectivas.

Examinando una serie de documentos en archivos españoles, guatemaltecos y mexicanos, saltan a la vista dos cuestiones de interés. Primeramente, la mayor parte de los textos fueron redactados en la Península Ibérica, circularon a través de las instituciones indianas y se adecuaron a las realidades y problemáticas del siglo XVIII. En segundo lugar, buena parte de ellos explicaron las plagas con posturas que amalgamaban pensamientos religiosos, mientras que una menor proporción las refieren a partir de razonamientos naturales.

Entrando en materia, puede decirse que uno de los primeros documentos que circularon en Guatemala y Nueva España y que sistematizaron y difundieron ciertas ideas sobre las plagas fue el Tratado de las langostas muy útil y necesario... (1620) de Juan de Quiñones, alcalde mayor de la villa de El Escorial. Hasta donde puede observarse, este manuscrito definió las plagas como una «calamidad mayor que existe en el mundo...» y como un «hecho que quitaba las esperanzas sembradas...»; asimismo, precisó que las langostas eran insectos que actuaban como «ovejas sin pastor, como repúblicas sin Rey, como ejércitos sin capitán y gobernador...» Desde la perspectiva de Quiñones, estas plagas debían entenderse como «castigos que Nuestro Señor envía a la tierra...» en respuesta a las conductas pecaminosas de los hombres, las desatenciones en el pago de diezmos y obvenciones, las prácticas paganas de ciertos grupos y los «ataques bestiales» hacia la iglesia. ${ }^{35}$

35. QuiÑONES, 1620: ff. 28, 32, 40 y 42. En el caso de Guatemala, esta obra aparece referenciada y transcrita parcialmente en «Providencias dadas para la extinción de la plaga de langosta que ha invadido los pueblos del valle de Guatemala, (1706)», Archivo General de Centroamérica (en adelante AGCA), AI.22.8.5369. 45.406. En el 
Una segunda obra que circuló en los reinos americanos fue Del origen y principio de la lengua castellana o romance... (1674) del canónigo de la catedral de Córdoba, Bernardo de Aldrete, quien definió las plagas como «llagas o heridas que provocan una calamidad», mientras que a las langostas las llamó «simples animales o insectos... que hacen daño en los frutos... y que suelen levantarse en el aire muchedumbres que cubren el sol...» No obstante, al unir estos vocablos, Aldrete resaltó el influjo de las ideas religiosas y afirmó que estos fenómenos eran una muestra de los «azotes de Dios por los pecados de los hombres..., azotes que causan llagas como las que causaron las plagas de Egipto... ${ }^{36}$ En este misma época y tesitura, un manuscrito titulado Despertador christiano de sermones... (1694), de la autoría del obispo gaditano Joseph de Barcia y Zambrana, reiteró que dichas plagas eran una «calamidad devota» que se acompañaban de insectos que «todo muerden..., consumen..., destruyen..., infestan el aire y engendran pestilencia...» Asimismo, afirmó que su aparición era una muestra de la ira de Dios hacia aquellos hombres que «no guardaron, sino quebrantaron la ley, repitiendo pecados... como la ingratitud..., el atrevimiento de los que niegan a Dios..., la codicia y lujuria insaciable..., y los sacrilegios que se cometen en la confesión...» ${ }^{37}$

Conviene señalar que la concordancia entre el catastrofismo referido y los hechos que implicó una plaga no fueron muy distantes, pues en las sociedades agrarias una cosecha afectada no fue solamente un problema económico, sino un suceso que trastornó la realidad. Es decir, cuando los sembradíos eran invadidos por los insectos sobrevino el hambre, la enfermedad y la muerte. De ahí, entonces, que el miedo se propagara y las ideas providencialistas se instalaran en las mentes humanas, prueba de ello son una serie de testimonios gestados durante las primeras décadas del siglo XVIII. En 1706, por ejemplo, las autoridades de la Real Audiencia de Guatemala referían la plaga de langosta como la irrupción de millones de insectos que «acá llamamos chapulín y que no deja milpa alguna, pues toda se la come...»; de la misma

caso de México, una copia del manuscrito se localiza Biblioteca Nacional de México (en adelante BNM), Fondo reservado, Reg. 14556.

36. AldRETE, 1674: ff. 85, 144.

37. BARCia y Zambrana, 1694: ff. 232-238. En el caso de México, esta obra puede localizarse en la Biblioteca de la Universidad de Guanajuato (en adelante BUG), Colección Conventual, Convento de San Antonio de Padua de San Miguel El Grande, BT 80 B3 1691. 
manera, advertían que su aparición era «repentina..., llega con los vientos recios y en forma de parvadas...» En cuanto a las razones de su presencia, las autoridades indicaban que eran resultado de la «flojedad mostrada por algunos pueblos... para evitar en todo o en parte los daños que ocasiona dicha langosta y su asiento en tan dilatadas y cuantiosas milperias...» Del mismo modo, advertían que uno de los recursos para extinguir estos padecimientos eran «los exorcismos y conjuros que dispone Nuestra Santa Madre Iglesia... $\gg^{38}$ Opiniones muy semejantes se gestaron en la Nueva España entre 1700 y 1730. Las autoridades de la villa de Saltillo, por ejemplo, notificaron en 1711 que padecían una escasez de granos debido a las «calamidades nacidas de la langosta y enfermedades que en dichos frutos y semillas tenemos..., situación por lo cual hemos de nombrar por patrón al glorioso san Agustín para que se digne de librar enfermedades, langostas, epidemias de dichas semillas y frutos... $»^{39}$ En 1726, por su parte, el gobernador de Yucatán -don Antonio de Figueroa- señalaba que, ante la escasez de lluvias y la presencia de langosta, esta provincia padecía una situación catastrófica, pues «faltaba el maíz (único grano para el sustento de los habitadores de esta provincia)..., por lo que los huesos de cualquier animal que se encontraban en los campos y calles los desbarataban entre dos piedras y se comían aquella harina, y en fin señor solo diré a vuestra merced que para recoger a los muertos me fue preciso hacer un carro y personalmente salir a recogerlos. Diez y siete mil son los que he podido numerar que fallecieron... en esta escasez y discordia... ${ }^{40}$

Es de advertir que, durante la segunda década del siglo XVIII, algunos oficiales adscritos a la provincia de San Salvador difundieron una perspectiva muy novedosa sobre las plagas; dicha postura intentaba distanciarse de la retórica bíblica y acercarse a razones físicas. Desde su perspectiva, las «plagas de chapulín» tenían su origen en las actividades volcánicas y las condiciones climáticas que se experimentaban en aquella jurisdicción, pues no era casualidad que tras experimentarse dos erupciones volcánicas -Santa

38. «Diligencias practicadas para el exterminio de la plaga de langosta asentada en varios pueblos de la provincia de Amatitlan, (1706)», AGCA, A1.1, leg. 5369, exp. 45407.

39. «Información sobre una plaga de langosta en Saltillo, (1711)», en GARCíA ACOSTA et al., 2003: 228.

40. «Informe del gobernador de Yucatán sobre la escasez de granos en la provincia, (1728)», Archivo General de Indias (en adelante AGI), México, 891, ff. 544-557. 
Ana (1723-1724) e Izalco (1730)- sobrevinieran largas temporadas de calor y secas, y -simultáneamente- las zonas agrícolas y ganaderas padecieran la presencia de acrídidos, situaciones que -en su conjunto- provocaban la ruina de los cultivos, el desplazamiento de la población y el brote de enfermedades. Debe decirse que estas opiniones tuvieron poco eco entre las autoridades de la época e incluso provocaron algunos comentarios críticos al respecto, al grado que ciertos religiosos de la villa de Sonsonate amenazaron con denunciar estas «opiniones infundadas» ante el Santo Oficio con miras a castigar a sus artífices. ${ }^{41}$

Relatos contrastantes se difundieron en Nueva España. En la provincia de Yucatán, por ejemplo, el alcalde ordinario y secretario mayor -Gerónimo del Puerto- señalaba en 1728 que la plaga de langosta que afectaba aquel territorio era resultado -entre otras cosas- de las conductas desplegadas por los naturales, quienes en «fuerza de su natural ocio y de la libertad en que se hallaban puestos no cultivaron sus sementeras..., muchos de ellos con el ánimo de que murieran o se ausentasen los españoles..., pero como castigo a esta suerte les ha llegado la plaga y la enfermedad... ${ }^{42}$ Años después, la Gazeta de México refería la presencia de esta amenaza en tierras yucatecas y sugería que los feligreses se arrepintieran de sus pecados e invocaran la mediación celestial, tal como lo habían practicado en las Filipinas al tiempo en que sus campos fueron invadidos por este insecto: "para lo cual se determinó traer por segunda vez de su santuario, extramuros de esta ciudad, a Nuestra Señora de Guía, como se hizo el día 1 de julio con la solemnidad acostumbrada, colocándola en la Santa Iglesia Catedral, donde se le hizo su novenario...» ${ }^{43}$

Así, no es casualidad que durante las primeras décadas del siglo XVIII la retórica bíblica sobre las plagas continuara predominando y que la Iglesia difundiera numerosos instrumentos para que sus párrocos enfrentaran estas

41. «Informe del común de San Andrés Apaneca sobre los daños causados por la erupción del volcán de San Ana (1723)», AGCA, AI. 24, leg 1584, f. 37; «Solicitud del pueblo San Juan Napubiales para enfrentar la plaga de langosta (1723)», AGCA, AI. 24, leg 1584, f. 37; «Solicitud del pueblo de Izalco para exonerarse del pago de tributos (1730)», AGCA, AI. 24, leg. 1587, exp. 10231.

42. «Informe del alcalde ordinario y secretario mayor de la provincia de Yucatán sobre la escasez de alimentos que se experimentan, (1728)», AGI, México, 891, ff. 599-604.

43. «Asia, (desde primero hasta finales de marzo de 1737)», en Gazeta de México, n. 112, p. 897. 
«amenazas apocalípticas» e intentaran paliar los daños que causaban en los campos y los temores que despertaban en la feligresía. A juzgar por algunos documentos, los párrocos se encargaron de instrumentar dichas medidas y hacer valer «el ritual romano que dictaban los libros sagrados para enfrentar los demonios obsidentes y postsidentes... y las criaturas irracionales e inanimadas... como son las plagas de langostas, ratones y otras sabandijas...» Con esta perspectiva, los religiosos se mostraban como «médicos públicos de la iglesia, adornados de la gracia de su curación...», mientras que las plagas eran entendidas como «males que destruyen los frutos de la tierra... y dañan a los fieles... en sus personas o en sus bienes...» ${ }^{44}$ Sin duda, las ideas del antiguo testamento eran los ejes que explicaban el origen y la evolución de estos fenómenos, y eran -sobretodo- los fundamentos que regulaban las acciones de la iglesia y de los grupos sociales frente a dichas amenazas. Por cierto, estas amenazas eran entendidas como encarnaciones de seres malignos que -a su vez- evocaban leyendas negras, poderes transgresores y conductas pecaminosas; inclusive, el hecho de vislumbrar a las langostas desde esta óptica fue una muestra de que el enjuiciamiento hacia los insectos revelaba una condición gestada por la Iglesia: donde el hombre aparecía como hijo de Dios con licencia para opinar sobre el mundo natural y donde los insectos eran proyectados a la luz de comportamientos irracionales. En este orden, la langosta fue un ente capaz de ser juzgado por las leyes divinas, ya sea por su irracionalidad, por su conducta inmoral y por las ideas y acciones perversas que generaba entre los individuos. ${ }^{45}$ Prueba de ello fue el caso de Juan Crispin, mulato oriundo del pueblo de don García en el altiplano de Guatemala, que fue turnado al Tribunal de la Inquisición en México por pronunciar repetidamente una serie de blasfemias hacia Dios y la Virgen María luego de que una plaga de langosta devastó sus campos de cultivo entre 1770 y 1772 . Desde la perspectiva del Santo Oficio, el citado mulato fue presa de la «conducta endemoniada... e irracional» que irradia la plaga en la especie humana, situación por la cual se instruyó al párroco de don García instrumentar una serie de conjuros y procedimientos contra el «animal destructor», así como practicar ejercicios espirituales con Juan Crispin para provocar su redención

44. CONCEPCiÓN, 1721: 166-170. XimÉNEZ, 1730: 35-36. LÓPEZ RubiÑos, 1741: 3-5. 45. LORA, 2013: 54. 
y arrepentimiento. ${ }^{46}$ Debo remarcar que este tipo de posturas resultaron muy obvias, especialmente si se considera que -durante estos años- el razonamiento espiritual continuaba explicando y fundamentando la realidad, así también se empleaba para contener las amenazas terrenales; de ahí que el clero ostentara la potestad de «razonar sobre las plagas...»y «exorcizar o conjurar la langosta, la peste, las fiebres y las demás cosas que por sí mismas o por malignidad del demonio pueden dañarnos... $\gg^{47}$

Dado esto, no es casual que -hasta bien entrado el siglo XVIII- circularan muchas opiniones de corte bíblico para explicar los orígenes y efectos de estas plagas. En 1771, el párroco de Santo Domingo del Palenque -en el obispado de Chiapas- advertía que la plaga y peste que prevalecía en aquella doctrina eran como «un castigo del cielo porque no ha valido remedio alguno para contenerlas... y es tanta la porción de langosta que hay en estos territorios y la que asoma por todas partes que solo el poder divino podrá destruirla... ${ }^{48} \mathrm{Un}$ año después, la mitra chiapaneca insistía en que la plaga que afectaba el occidente de Guatemala era como «una tormenta que moja a nuestro rebaño... con el hambre y la peste..., que no sin abundantes lágrimas de nuestros corazones nos decaesen el ánimo... ${ }^{49}$ Comentarios semejantes se desplegaron en Nueva España. Basta citar las opiniones de algunos oficiales reales. En la Villa de Valles -provincia de San Luis Potosí- las autoridades precisaron que, de «forma azarosa y repentina..., ha hibernado y ahuevado cantidad de innumerable langosta... como si fuera un castigo divino...», dejando daños considerables en las zonas de cultivo. Por su parte, los naturales de Yahualica también explicaron la aparición de estos insectos bajo el argumento de que se trataba de un «hecho extraño..., pues como una ocurrencia o un castigo... llega con tanta abundancia que no deja arbitrio alguno en solicitud de alivio y refugio, pues enteramente destruye y aniquila las sementeras que están ya

46. «Contra el mulato Juan Crispin por blasfemia (1772)», Archivo General de la Nación de México (en adelante AGNM), Inquisición, vol. 1178, exp. 13.

47. LÓPEZ RUBiÑOS, 1741: 3.

48. «Informe de Marcos Novelo, párroco de Palenque, sobre la presencia de langosta (1771)», Archivo Histórico Diocesano de San Cristóbal (en adelante AHDSC), Palenque IV D1, carpeta 1678, exp. 1.

49. «Cordillera para que los curas animen a sus feligreses a que fomenten sus sementeras, (1771-1772)», AHDSC, Fondo Diocesano, Carpeta 3690, exp. 9. 
creciendo e impide el que los recientes sembrado puedan producir el fruto, respecto a que taladran las tierras y no la dejan fructificar en todo género de especie como caña, maíz, frijol, algodón y demás...» ${ }^{50}$

Sin duda, esta permanencia del pensamiento apocalíptico y azaroso puede explicarse a partir de tres fundamentos: primeramente, el peso que tenía la iglesia en las sociedades de antiguo régimen, ya sea para modelar la manera de pensar, entender el mundo y atribuirle significados a la realidad; en segundo lugar, la exegesis que se construyó, difundió y aprendió en los territorios indianos sobre los fenómenos y las amenazas naturales; en tercer lugar, el compromiso que existía entre los escritos referidos y los fundamentos de una filosofía natural cimentada en las ideas providenciales y la especulación. ${ }^{51}$

Diversas fuentes revelan que -desde 1740- varias obras comenzaron a cuestionar estos enfoques y dieron paso a reflexiones cimentadas en razonamientos lógicos y experiencias concretas. ${ }^{52}$ Prueba de ello son los manuscritos que circularon en Guatemala y Nueva España, y que sirvieron de plataforma para elaborar ensayos, pareceres, reglamentos y ordenanzas para comprender y enfrentar dichas plagas. Por ejemplo, en la Instrucción formada sobre la experiencia y práctica de varios años para conocer y extinguir la langosta..., elaborada por el Consejo de Castilla en 1755, las langostas fueron referidas como insectos llanos que «hacen daño..., aniquilan lugares... y acaban las cosechas de los reinos...», mientras que las plagas fueron enunciadas como «agrupaciones de insectos que... al llegar a la edad adulta vuelan... y consumen todo... hasta dejar los sitios destruidos...» Con un enfoque racionalista, la Instrucción advirtió que estos fenómenos se originaban cuando los insectos depositaban sus huevecillos en la corteza terrestre y-especialmente-cuando estos germinaban y daban paso a los saltones que devastaban toda la cubierta vegetal. Es de advertir que la Instrucción fue muy precisa al referir que los bichos aparecían y desovaban bajo condiciones meteorológicas muy singulares: escasez de humedad y temperaturas calurosas. Como puede observarse, el

50. «Consulta del justicia de la villa de Valles sobre una plaga de langosta (1774)», AGNM, Indiferente virreinal, caja 5027, exp. 68; «Parecer de los naturales de San Juan Bautista Yahualica, (1777)», AGNM, Indios, vol. 48, exp. 68.

51. DARnTON, 1987: 11-15. TrABUlSE, 2010: 19-20. CAÑIZARES ESGUERRA, 2008: 54-55.

52. Entre las obras que refieren este tipo de desarrollo racionalista destacan: DIE MACULET y Alberola Romá, 2015 y FERnÁndez Baños y Arias Simarro, 1985: 9-28. 
pensamiento racionalista comenzó a desplazar la perspectiva providencialista sobre los orígenes de las plagas. ${ }^{53}$

Otra obra que aglutinó ideas novedosas sobre el mundo natural y que circuló ampliamente en los territorios estudiados fue la Introducción a la Historia Natural y a la Geografía Física de España... del naturalista irlandés Guillermo Bowles. En este trabajo, el autor definió la langosta como una «especie de insecto» que suele proliferar en las «dehesas y tierras no cultivadas», y con la capacidad suficiente para «devorar el reino vegetal..., causar los horrores del hambre y la miseria..., esparcir la calamidad... y llevar consigo el terror y la desolación...» Asimismo, empleo la voz plaga para referir la «agrupación prodigiosa de insectos», e inclusive la utilizó para mencionar un proceso natural en el que ciertas especies se multiplican «de manera extraña o problemática...» Desde la perspectiva de Bowles, la langosta fue un animal inofensivo en su estado solitario y bajo condiciones ambientales estables. No obstante, remarcó que dicha pasividad se perdía al tiempo en que las temperaturas aumentaban y los niveles de humedad descendían. En este orden, refirió que las langostas eran «termómetros vivos, que indican el calor respectivo de cada paraje donde se halla, y de su diferente temperamento procede, como vamos advirtiendo, el diferente tiempo en que se ven las bandadas de langostas...» Sin duda, las observaciones del naturalista irlandés derivaron de conocimientos biológicos, registros climáticos, observaciones físicas y reflexiones propias de la tradición fisiocrática. Desde esta perspectiva, tengo la impresión de que la obra de Bowles concretó una propuesta novedosa que invitaba a pensar las plagas de insectos como fenómenos cuyos orígenes debían buscarse en las condiciones ambientales, los cambios meteorológicos y las características geográficas de ciertos territorios. ${ }^{54}$

53. La obra original es la «Instrucción tomada sobre la experiencia, y practica de varios años, para conocer y extinguir la langosta en sus tres estados de ovación, feto o mosquito, y adulta, con el modo de repartir, y prorratear los gastos, que se hicieren en este trabajo, (1755)», Biblioteca Nacional de España (en adelante BNE), Reales Cédulas y órdenes promulgadas sobre asuntos de gobierno, Signatura R/37083, capítulos I-III, X-XIV. Una réplica de esta instrucción puede localizarse en AGNM, Bandos, vol. 22, exp. 63. Asimismo, puede localizarse en el AGCA, AI.22.8, leg. 4564, exp. 39101.

54. BOWLES, 1789: 238-239, 249-251. 
Muy cercanos a los planteamientos de Bowles, las autoridades del cabildo de Guatemala advirtieron -entre 1770 y 1772- que dichas plagas guardaban una correspondencia directa con las condiciones del clima, los niveles de humedad y las posibilidades ecológicas de los terrenos. Es decir, desde la perspectiva del cabildo, el calor y la sequía eran la base para que los insectos se reprodujeran y alcanzaran su condición endémica, tal como había ocurrido en las provincias de Petapa y Chiapas, espacios donde «la destrucción y la desolación son motivo de que la langosta se ha situado por más de cuatro años en aquellas provincias... y donde por la desdicha y miseria que esta plaga acarrea ha llegado a valer la fanega de maíz hasta cincuenta pesos... ${ }^{55}$ Para estas mismas fechas, la Audiencia de Guatemala subrayó que, debido a las irregularidades en las «lluvias y vientos, y en los caprichosos calores y fríos...», se tenía conocimiento de la irrupción de una plaga de langosta en los valles inmediatos a la ciudad de Guatemala, situación por la cual se instaba a los alcaldes mayores y autoridades de pueblos a destinar todos los recursos para evitar la escasez de granos. ${ }^{56}$ Enriqueciendo esta postura, el gobernador de Yucatán señaló -en 1770 - que, tras el paso de varios huracanas y el aumento de temperaturas, aquella provincia había recibido una plaga de langosta que «da como resulta la pérdida de cosechas, algodones y frutos..., y precisa la despoblación y otros perjuicios, y la escasez de caudales... ${ }^{57}$ Años después, un informe del virrey Antonio María de Bucareli y Ursúa también ponderaba el influjo de las condiciones climáticas como causa posible para explicar la presencia de estas plagas. Refiriendo la situación que enfrentaba la provincia de Oaxaca, el virrey señaló que, debido a la escasez de lluvia en la década de 1770-1779, se tuvo la «presencia de langosta... y las cosechas de maíz que se cogieron en esta provincia y demás de sus contornos fueron sumamente cortas... y se ha padecido mucha hambre...» ${ }^{58}$

55. «Providencias dictadas por el Ayuntamiento de Guatemala para exterminar la langosta (1771)», AGCA, A1.2, leg. 2820, exp. 24983.

56. «Providencias dictadas por la Real Audiencia de Guatemala para combatir la plaga de langosta (1771-1772)», AGCA, A1.1, leg. 8, exp. 186.

57. «Informes sobre los problemas que acontecen en la provincia de Yucatán (1769-1772)», AGI, México, 3054.

58. «Informe sobre la situación agrícola en Nueva España (1779-1780)», AGI, México, 1867. 
Debe subrayarse que si bien el periodo 1780-1796 fue muy representativo respecto a las pulsaciones climáticas que se presentaron en todo el globo terráqueo, también es verdad que fue una época muy limitada en cuanto a la producción de materiales que aglutinaran conocimientos para comprender las formas en que surgían y evolucionaban las plagas referidas. Tal vez la excepción pueda encontrarse en algunas colaboraciones que aparecieron en el Diccionario castellano con las voces de ciencia...; el Mercurio de España; la Gaceta de Madrid; el Diario curioso, erudito, económico y comercial; y el Semanario de agricultura y artes dirigido a los párrocos; así como las obras de Ignacio Asso del Río y Juan Antonio Zepeda y Vivero.

Sobre las colaboraciones referidas, puede decirse que se distinguieron por incorporar reflexiones que vinculaban el origen de las plagas con las alteraciones climáticas, y -sobre todo- precisar la manera en que el clima trastornaba la conducta de los insectos y propiciaba su reproducción física: «la langosta se multiplica prodigiosamente guando el tiempo cálido favorece sus crías: que una vez multiplicada y propagada, son vanos todos los esfuerzos y precauciones humanas para extirparla y que el remedio eficaz no es otro que el que facilita próvida la misma naturaleza de una estación contraria a su temperamento, con las lluvias copiosas, granizos fuertes y fríos recios; pues aunque las aves y otros animales la persiguen mucho, son débiles enemigos para extirparla... ${ }^{59}$ En este mismo tenor, apuntaron que las pulsaciones climáticas eran tan complejas que lo mismo podían provocar plagas de langosta que invasiones masivas de pájaros, orugas, ratones, alacranes u otras especies perniciosas: «durante algunos días, casi nos han obscurecido el sol las bandadas de gaviotas que han acudido aquí, y nos han libertado, por mucho tiempo según podemos inferir, de la langosta que talaba nuestras mieses, haciéndonos el mayor beneficio en libertarnos de insectos tan voraces y perjudiciales. Lo más singular es que, como si dichas aves únicamente hubiesen venido a exterminar aquella plaga cruel, desde que acabaron con la langosta, no han vuelto a aparecer en estos contornos. Veinte años consecutivos hemos padecido la calamidad de la langosta, la cual destruyendo nuestros sembrados ha provocado hambre y miseria, por la falta de granos... ${ }^{60}$ Por si esto no fuera

59. «Plagas», en Diario curioso, erudito, económico y comercial, n. 107 (1786): 58. 60. «Esmirna», en Mercurio de España, septiembre 1786, tomo III: 11. 
suficiente, también plantearon que el clima era un factor que trastornaba el ciclo biológico de los insectos, al grado de reducir la comunidad de machos y multiplicar la de hembras, con lo cual la población animal se incrementaba, perpetuaba su ciclo de vida y provocaba daños considerables en la cubierta vegetal. ${ }^{61}$

En lo que respecta a la obra de Asso del Río, El discurso sobre la langosta... (1786), se distinguió por definir las plagas como agrupaciones de animales que infestaban los campos, pues «son muchedumbres de insectos que componen la más dilatadas especies del reino animal, ninguno se halla tan perjudicial como la langosta, a causa de los gravísimos daños que ocasiona y de la grande dificultad que hay para precaverlos...»; asimismo, por referir a la langosta bajo los preceptos de Carlos Linneo, es decir como una «especie que deteriora los campos verdes... y que aumentan las públicas calamidades, porque se establecen en las regiones, de donde no son originarios, y se propagan por espacio de algunos años...» Al igual que los naturalistas ilustrados y los políticos fisiocráticos, Asso del Río explicó que dichas plagas tenían su origen en dos situaciones: primeramente, la «prodigiosa extensión de eriales..., terrenos incultos... y campos secos... donde las hembras desovan...», y que -desde su perspectiva- proliferaban en toda la monarquía debido a los beneficios que acumulaban los pueblos, los ayuntamientos, los señoríos y las corporaciones (civiles y religiosas); en segundo lugar, las condiciones atmosféricas extraordinarias que prevalecían en ciertos espacios de la monarquía hispanas, tales como «la aridez, el calor y la sequedad..., causas que combinadas entre sí pueden promover y aumentar la fecundidad de los insectos...» ${ }^{62}$

La obra de Zepeda y Vivero, Agricultura metódica... (1791), planteó reflexiones más elaboradas sobre los factores que posibilitaban las buenas y las malas cosechas en el campo español. De entrada, cuestionó abiertamente aquellas opiniones de corte providencial que explicaban los orígenes de las plagas en función de que «la langosta es un instrumento de que se vale la divina justicia para castigar los pecados; y a la verdad, teniendo presente la plaga de langosta con que Dios castigó a Egipto, porque el Faraón no le quiso obedecer, y las muchas y repetidas veces que por medio de los

61. TERREROS Y PANDO, 1786: 418-419.

62. ASSO Y DEL RIO, 1785: 3, 8, 10 y 13.

Revista de Historia Moderna, n. ${ }^{\circ} 35$ (2017) (pp. 214-253) | ISSN-e: 1989-9823 | ISSN: 0212-5862 
profetas amenazó a los pueblos de Israel, si no se emendaban con la langosta, diciendo unas veces que les asolaría los sembrados...»; por el contrario, el autor subrayó la necesidad de comprender el papel que jugaban las estaciones climáticas y los fenómenos de la naturaleza en el desarrollo de estas amenazas, pues «las estaciones de los tiempos concurren más o menos a moderar o coadyuvar a la explicación de las virtudes y los defectos en el campo...» Con este enfoque, Zepeda y Vivero propuso que la langosta aparecía en forma de plaga según el comportamiento de «los climas, según las alteraciones de los tiempos, y según los influjos de los astros...» En este horizonte, el autor advirtió que la escasez de humedad, el exceso de calor y la disponibilidad de campos eriazos eran los elementos fundamentales para propiciar la aparición de los insectos: «la langosta es animal libidinoso y fecundo, de manera que cuando está de su parte la naturaleza se multiplica todos los años...» Sin duda, los argumentos de Zepeda y Vivero resultaron sumamente novedosos y propositivos para explicar el desarrollo de estas plagas desde la confluencia del clima, la biología de los insectos y las condiciones geográficas de las áreas afectadas. ${ }^{63}$

Como puede observarse, las nociones sobre las plagas de langosta experimentaron una serie cambios a lo largo del siglo XVIII, siendo los más evidentes aquellos que se centraron en explicar los orígenes y la evolución de dichos fenómenos. Así, durante esta época, las percepciones escolásticas y providencialistas que se tenían sobre estas amenazas fueron suplantadas -poco a poco- por una serie de conocimientos inspirados en el razonamiento biológico, en los registros climáticos y en la experiencia física. Dado esto, no fue casualidad que durante la segunda mitad del siglo XVIII, las autoridades de Guatemala y Nueva España manejaran una serie de recursos donde las plagas de acrídidos eran referidas como hechos de la naturaleza que estaban vinculados con las oscilaciones del clima y que demandaban toda la atención de la población, pues su presencia ponía en riesgo las actividades agrícolas, el orden público y los intereses económicos de la Corona. Ante este contexto, conviene plantear una revisión de las opiniones que se difundieron entre 1797 y 1805 en los espacios de estudio, toda vez que se trata de un periodo donde la imprenta, los conocimientos científicos y las políticas utilitaristas

63. ZEPEDA Y VIVERO, 1791: 62-63, 158-162.

Revista de Historia Moderna, n. ${ }^{\circ} 35$ (2017) (pp. 214-253) | ISSN-e: 1989-9823 | ISSN: 0212-5862 
de la Corona coadyuvaron profundamente en la configuración de nuevas perspectivas sobre estos insectos.

\section{Las plagas bajo el resplandor de las luces}

Si bien la Ilustración fue una corriente que suplantó -poco a poco- las ideas de corte religioso que explicaban el mundo natural y dio paso a una serie de argumentos fundados en razones lógicas y experiencias empíricas, también es verdad que fue una tradición que cimentó las bases para que los campos agrícolas dejaran de percibirse como simples terrenos que perpetuaban cultivos y estructuras de antiguo régimen, y comenzaran a vislumbrarse como espacios dispuestos a transformarse, transferirse y proclives a saciar las necesidades económicas de las naciones y los individuos. ${ }^{64}$ Dado esto, no fue casualidad que -durante la segunda mitad del siglo XVIII- circularan en la monarquía hispana una serie de ideas donde dichos campos se entendían como «una fuente de la riqueza particular...», un «manantial de abundancias...», un «recurso que asegura los abastos de la población...»y un «medio que hace florecer los Estados...»; asimismo, una serie de planteamientos donde todos los elementos que afectaban dichos terrenos eran vislumbrados como "obstáculos», «amenazas», «estorbos» o «impedimentos» del bien común. ${ }^{65}$ Cabe señalar que estas nociones fueron una muestra del influjo que tuvo el pensamiento fisiocrático, el liberalismo económico y el razonamiento científico; asimismo, fueron parte de una agenda reformista que consideraba que: «un Estado sin agricultura será siempre precario, penderá siempre de aquellos pueblos de quienes recibe sus materias y en quienes consuma sus productos...; la agricultura puede levantar un Estado, su solidez y su grandeza...; debemos protegerla de toda amenaza..., porque este es el más seguro, más directo y más breve medio de criar una poderosa industria y un comercio opulento...; defendámosla y liberémosla de los estorbos físicos o derivados de la naturaleza...» ${ }^{66}$

64. Paquette, 2014: 73-92. Alberola Romá, 2016: 21-42. Calvo, 2010: 96.

65. RODRÍGUEZ CAMPOMANES, 1774; 1789; JovElLANOS, 1795.

66. «Informe de la Real Sociedad Económica de Madrid al real y Supremo Consejo de Castilla en el expediente de Ley agraria extendido por el autor a nombre de la junta 
Como era de esperarse, estas nociones se difundieron ampliamente en los territorios indianos. A juzgar por la experiencia de Guatemala y Nueva España, puede decirse que dichas perspectivas florecieron a la luz de iniciativas que buscaban -entre otras cosas- mejorar la situación del campo, maximizar su explotación, reformar su estructura jurídica y abatir los numerosos factores que imposibilitaban su desarrollo. Sobre esto último, buena parte de las reflexiones se centraron en una serie de fenómenos y amenazas naturales que aparecían intempestivamente y devastaban los campos agrícolas. Obviamente, las plagas de langostas quedaron comprendidas en este horizonte.

Examinando algunos manuscritos que circularon entre 1797 y 1805 , puede decirse que las nociones vertidas sobre las plagas de langosta se plantearon a la luz de tres grandes enfoques. El primero de ellos se distinguió por mostrarlas en contextos donde predominaban las pulsaciones climáticas y los trastornos ambientales; es decir, escenarios donde situaciones propias del medio ambiente provocaban cambios en la biología y el comportamiento de los insectos, y alentaban la formación de grandes comunidades que luego devastaban los campos en busca de alimento. Sobre estos sucesos, algunos autores anotaron que el clima era «un compuesto de poderes y de influencias que las plantas y los animales, con todas la cosas que respiran contribuyen a promover en sus mutaciones recíprocas... para alterarle por el arte... y contribuir de varios modos a la alteración de los temperamentos... ${ }^{67}$ Otros testigos de la época plantearon que las plagas eran resultado de los remanentes que dejaban las heladas extraordinarias. Inclusive, los editores de la Gazeta de Guatemala anotaron que:

Las noticias que han esparcido vuestras mercedes de sus gacetas con motivos de los estragos que por esas regiones ha hecho el chapulín en las milpas de maíz, nos han refrescado las tristes memorias que permanecen aún en este reino por igual infortunio provenido de las heladas extemporáneas del año de 78. Desde esta infeliz época se advierte con efecto en toda clase de gente un

encargada de su formación (1795)», en JOVELLANOS y LINARES Y PACHECO, 1840: t. VII: 29-185.

67. «Alteraciones de los climas», en Gazeta de Guatemala, 246 (15 de febrero de 1802). 
cuidadoso sobresalto en las precisas temporadas que se asoma el frío, hasta ver completamente alzadas las cosechas corrientes del campo. ${ }^{68}$

En este mismo tenor, algunos oficiales de Nueva España y Guatemala advirtieron que las plagas eran fenómenos que sobrevenían con las sequías y que, desde la perspectiva oficial, eran atípicos «en términos que aquí nunca se había experimentado, lo que es causa de que las siembras de postrera no puedan hacerse con generalidad...»; hechos extraordinarios ya que «ni en lo más riguroso... se ha experimentado la aridez que ahora hay en estas provincias; apenas ha caído una u otra agua, y no hay ejemplos en muchos años de una escasez de agua semejante...»; obviamente, bajo el horizonte de la sequía, los insectos proliferaban hasta convertir algunas regiones en «tierras eriales, como los grandes desiertos de la Libia... ${ }^{69}$

Otras fuentes difundieron ideas que -paradójicamente- años atrás habían sido censuradas por las instituciones monárquicas. Me refiero a los planteamientos que explicaban las plagas a partir de las erupciones volcánicas y los daños ambientales que estas causaban, factores que -en su conjuntodespertaban la ferocidad de los insectos. De manera puntual, estas nociones señalaron que las erupciones del volcán de Izalco (provincia de San Salvador) - acaecidas entre 1802 y 1803- eran la causa de estas amenazas, pues «la columna de humo y ceniza coge más de nueve leguas... y por donde atraviesa causa tal daño... que marchita cualquier sementera si la halla tierna y si tiene algún vigor la deja casi imposibilitada de fructificar, sino como la mitad de lo que pudiera rendir, según se experimentó el año último... ${ }^{70}$ Inclusive, las autoridades de Sonsonate coadyuvaron esta postura y se pronunciaron en la mejor tradición científica de la época con el argumento de que: «las erupciones de este volcán han seguido y siguen en mucha cantidad, causando bastante daño en las siembras de frijol de los pueblos fríos, que es por donde comúnmente toma su curso la manga de cenizas. Además de este enemigo,

68. «Informe del subdelegado de Teotitlán del Valle (1804)», Archivo General del Poder Ejecutivo de Oaxaca (en adelante AGEPEO), Real intendencia, Subdelegaciones, Teotitlán del Valle, exp. 41, ff. 1-3; «Pósitos», en Gazeta de Guatemala, 294 (8 de marzo de 1803).

69. «Noticias de este reino», en Gazeta de Guatemala, 326 (24 de octubre de 1803); «Granada de Nicaragua», en Gazeta de Guatemala, 31 (4 de septiembre de 1797)»; «Nicaragua y Costa Rica», en Gazeta de Guatemala, 142 (3 de febrero de 1800).

70. «Volcán de Izalco», en Gazeta de Guatemala, 323 (3 de octubre de 1803). 
tienen algunos otros pueblos el del chapulín, que anda vagueando... Varios sembrados han padecido por una o por ambas causas la destrucción... $\gg^{71}$

El segundo enfoque que se utilizó para vislumbrar las plagas se planteó desde el campo de la economía y, específicamente, desde el sector agrícola. Sin duda, esta apreciación tuvo sus orígenes en la tradición fisiocrática que vislumbraba la agricultura como el manantial de un Estado que «alimenta a los hombres y proporciona las artes, siendo como el tronco de un árbol sobre el cual toman su incremento todas las ramas...», mientras que los elementos que trastocaban -directa e indirectamente- el campo se visualizaron como «piezas discordantes», «infortunios», «suceso infaustos», «llagas», «heridas» y «ofensas absolutas». ${ }^{72}$ Así las cosas, no fue extraño que la langosta se percibiera como un animal que devoraba cultivos, provocaba ciclos de escasez y -sobre todo- propiciaba oscilaciones bruscas en los valores de los granos. Sobre esto último, las nociones fueron claras y contundentes: los «chapulines..., los insectos... y la langosta voladora... son la causa de la carestía del maíz y demás artículos... $\gg^{73}$ Opiniones muy semejantes se difundieron en el virreinato de Nueva España, donde dicha plaga fue avizorada como un ente que «daña los mercados y trojes de los particulares... y provoca el excesivo precio de las semillas». ${ }^{74}$ Todo parece indicar que, desde el pensamiento ilustrado, esta noción fue muy lógica ya que los insectos eran entes que alteraban los «precios equitativos», sojuzgaban la libertad de competencia entre los productos y trastornaban el orden público.

En paralelo con este enfoque, las plagas también se concibieron como fenómenos que alteraban las conductas humanas: por un lado, provocando que los hombres vivieran bajo el influjo del miedo y temor; por otro lado, despertando en muchos de ellos el apetito de la codicia, la acumulación y la especulación. Los testimonios al respecto son abundantes. Unos refieren

71. «Sonsonate», en Gazeta de Guatemala, 326 (24 de octubre de 1803).

72. LARRAZABAL, 1811: 25.

73. «León», en Gazeta de Guatemala, 89 (1 de septiembre de 1798). «Informe del intendente de Oaxaca para combatir la plaga de langosta (1804)», AGNM, Civil, vol. 1701, exp. 3, ff. 100-100v.

74. «Noticia de las providencias dictadas para el exterminio de la plaga de langosta que apareció en la provincia de Oaxaca (1802)», AGNM, Impresos oficiales, vol. 25, exp. 27. «Informe del subdelegado de Teotitlán del Valle (1804)», AGEPEO, Real intendencia, Subdelegaciones, Teotitlán del Valle, exp. 41, ff. 1-3. 
que, cuando las plagas proliferaban, los comerciantes y oficiales lucraban con la «desgracia... y encarecen los alimentos... y desatienden los valores patrióticos...»; otros plantearon que dichas conductas eran enfermizas ya que «provocan que los hombres mendiguen la subsistencia... y se expongan a la penuria de la necesidad...»; las opiniones más comunes se tradujeron de la siguiente forma: «esta calamidad es la causa de que en el día se deje de vender la fanega de maíz en ocho reales... y hoy se venda a cinco y seis pesos... ${ }^{75}$

El tercer enfoque se distinguió por amalgamar la vieja tradición cristiana del bien común y la perspectiva fisiocrática sobre el orden público. En este sentido, las plagas se entendieron como fenómenos que trastocaban la vida de los súbditos, los intereses de la monarquía, las funciones de las instituciones y la dimensión temporal de la iglesia. Hasta donde puede observarse, esta postura consideró que los efectos más nocivos de las plagas se concentraron en dos temas: el abasto de granos y el desplazamiento de la población. Sobre el abasto de granos, las apreciaciones giraron en torno a los problemas que causaba la plaga en la recolección de cosechas, la distribución de recursos, la mediación de tratos, los procesos de mercadeo, la regulación de precios y la acumulación de bastimentos. ${ }^{76}$ Así, no fue extraño que -entre 1797 y 1805- circularan en Guatemala y Nueva España numerosas ordenanzas, instrucciones y providencias donde se instaba a la población -entre otras cosas- a "proteger las siembras...», «fomentar cultivos extraordinarios...», «resguardar trojes...», «impedir la escasez y carestía de granos...», «procurar el beneficio público...», «socorrer a los más afectados...»y «combatir el hambre...» Obviamente, este interés por paliar el desabasto fue un reflejo de la tradición que procuraba el bien común; es decir, hacer todo lo posible para alcanzar el bien de los súbditos en tanto formaban parte de una monarquía; disponer medidas para que los pueblos alcanzaran su fin principal: vivir en

75. «León», en Gazeta de Guatemala, 89 (26 de noviembre de 1798); «Acción generosa», en Gazeta de Guatemala, 263 (14 de junio de 1802); «El reino de Guatemala», en Gazeta de Guatemala, 283 (1 de noviembre de 1802); «Sonsonate», en Gazeta de Guatemala, 287 (29 de noviembre de 1802). «Bando para combatir la plaga de langosta en Nueva España (1802)», AGNM, Bandos, vol. 22, exp. 63. «Noticia de las providencias dictadas para el exterminio de la plaga de langosta que apareció en la provincia de Oaxaca (1802)», AGNM, Impresos oficiales, vol. 25, exp. 27..

76. Una reflexión muy semejante y de mayor amplitud puede encontrarse en QUIROZ, 35 (2011): 35-59. 
orden y policía; y contar con preceptos para que las instituciones -temporales y espirituales- velaran por sus gobernados.

Sobre el desplazamiento de contingentes humanos, conviene decir que las plagas se vislumbraron como fenómenos que alteraban la vida rural y -en muchas ocasiones- ponían en riesgo la vida de aquellas familias que dependían de los cultivos y las tareas de recolección, ya sea para subsistir como unidad doméstica o para garantizar el sustento de sus animales. En efecto, cuando las plagas alcanzaron su fase activa sobrevino la muerte y el desplazamiento de «hombres que apenas pueden caminar..., que hacen gala de la indigencia y... engrosan la comunidad de mendigos... $\gg^{77}$ Ante este escenario, las autoridades se vieron obligadas a mantener el bien común y procurar por todos los medios el orden público. De ahí, entonces, que -entre 1797 y $1805-$ las autoridades de los territorios afectados organizaran a cada momento cuadrillas de trabajadores para perseguir los insectos, costearan entre la población la captura y exterminio de los bichos, instauraran la beneficencia pública en las provincias, solicitaran donativos a consulados y gremios de comerciantes para instrumentar dichas tareas, distribuyeran entre los pueblos una serie de instrucciones y herramientas para contener el flagelo, emprendieran concursos para colectar enjambres, dispensaran el pago de obvenciones y tributos a los pueblos afectados, coadyuvaran en la reubicación de los asentamientos que padecían la presencia de estos animales y organizaran trabajos públicos para mantener ocupados a los individuos que engrosaban las filas de desplazados y mendigos.

Es muy probable que -durante los primeros lustros del siglo XIX- las perspectivas sobre las plagas adquirieran un matiz complejo y diverso, ya sea por la experiencia acumulada durante el periodo colonial, por el progresivo desplazamiento de las ideas de corte providencialistas y -especialmentepor las innovaciones que proporcionaba el racionamiento científico de la época. Sea de ello lo que fuera, lo cierto es que -entre 1797 y 1805- las plagas que invadieron el reino de Guatemala y el sureste de Nueva España se concibieron desde el ámbito institucional como fenómenos propios de la diversidad natural, alteraciones que guardaban vínculos con la cuestión

77. «Reglas dictadas por el intendente de Oaxaca para el exterminio de la langosta (1804)», AGNM, Civil, vol. 1701, exp. 3, ff. 34-40. 
climática, amenazas biológicas propias de dichos terruños, obstáculos para el desarrollo de la agricultura, agentes que aturdían la economía y entes que apremiaban el bien público.

\section{Comentarios finales}

A lo largo de estas páginas he tratado de mostrar cómo un conglomerado de discursos que existían en el mundo occidental sobre las plagas de langosta fue transferido, aclimatado y asimilado en los territorios de Guatemala y Nueva España durante el siglo XVIII. Con este propósito, he subrayado que la relación entre el hombre y el mundo animal, así como la presencia de relatos religiosos, fueron el cimiento de una primera noción. En cuanto a la relación entre el hombre y el mundo animal, sobresalió una perspectiva donde las plagas de langosta fueron concebidas -tanto en la etapa precolombina como colonial- como un hecho azaroso e improvisto que implicó la escasez de recursos, la amenaza y la competencia entre hombres y animales por el acceso a los medios que garantizaban la subsistencia de cada especie. Es de advertir que dicha visión se enriqueció sistemáticamente durante la etapa colonial, especialmente a la luz del cristianismo. En este orden, los discursos sobre las plagas de Egipto y los caballeros del Apocalipsis proporcionaron los elementos suficientes para vincular las comunidades de insectos con horizontes donde predominaba la catástrofe, la escasez, el hambre y la enfermedad. Por si esto no fuera suficiente, la tradición bíblica agregó componentes que -por un lado- ponderaron el comportamiento de los hombres y -por otro ladorelacionaron dichas conductas con la naturaleza indómita de las Indias. Así, tanto la conducta humana como el proceder de la naturaleza fueron vistos como amenazas, factores que provocaban la ira divina y -por ende- hechos que provocaban la presencia de «plagas que manda Dios a las provincias, reinos o lugares, en castigo y pena de sus culpas... ${ }^{78}$ Como era de esperarse, estas nociones se difundieron y cobraron vigencia a través de las instituciones religiosas y civiles de Guatemala y Nueva España; así también, a la luz de escritos, imágenes y prácticas cotidianas que cimentaron el sistema de dominación colonial y definieron la naturaleza del Nuevo Mundo.

78. Diccionario de la lengua castellana, 1734: 358. 
Simultáneo a la proliferación de estas perspectivas, he mostrado la manera en que las ideas seculares sobre las plagas se introdujeron en los espacios de estudio y adquirieron relevancia en función de circunstancias concretas. Si bien resulta imposible determinar el influjo que tuvieron estas nociones, lo cierto es que su presencia posibilitó un horizonte para vislumbrar y comprender la presencia masiva de los insectos; horizonte donde se amalgamaron descripciones físicas de los animales, razonamientos sobre su conducta depredadora, apreciaciones sobre el clima, creencias religiosas e interpretaciones catastrofistas sobre la naturaleza. No obstante, debo subrayar que -durante el siglo XVIII- este horizonte fue sometido a críticas y revisiones por parte de los ministros, oficiales y científicos de la monarquía hispana. Sin duda, el resultado de este proceso fueron una serie de ideas donde las plagas de langosta comenzaron a vislumbrarse como amenazas naturales que surgían en geografías donde imperaban condiciones ambientales adversas, trastornos climáticos y alteraciones en la vida animal y vegetal. Esta nueva perspectiva sobre las plagas puso de relieve tres hechos: primeramente, la manera en que las ideas racionalistas comenzaron a desplazar los contenidos providenciales sobre las plagas; en segundo lugar, la forma en que las ideas seculares posibilitaron que los hombres convalidaran una vieja apreciación donde las plagas eran percibidas como amenazas biológicas y no necesariamente como expresiones de la furia divina o las fuerzas demoniacas; en tercer lugar, las posibilidades que estos hechos abrieron para comprender que los tiempos atmosféricos y las condiciones de la vida silvestre en Guatemala y Nueva España eran previsibles de entenderse, estudiarse y pronosticarse.

Hasta donde puede observarse, las nociones más elaboradas que se plantearon sobre las plagas de langosta se difundieron durante la segunda mitad del siglo XVIII y derivaron del pensamiento ilustrado. Como he tratado de probar, los conocimientos científicos y las políticas utilitaristas de la época coadyuvaron en la configuración de nuevas perspectivas sobre las plagas de insectos; plagas que fueron concebidas y mostradas como escollos de la agricultura, obstáculos de la economía, amenazas del bien común y flagelos del orden público. Por si esto no fuera suficiente, el pensamiento económico se dio a la tarea de rescatar indicios del cristianismo primitivo y ajustar lo necesario para plantear que las plagas eran tan influyentes en la vida provincial que -inclusive- su presencia provocaba el encarecimiento de granos, la 
acumulación de recursos, el colapso de los mercados y la proliferación de la usura. Finalmente, puede decirse que estas ideas sobre las plagas se definieron en función de la experiencia acumulada durante la etapa colonial, el influjo del pensamiento providencialista, el desarrollo de planteamientos naturalistas $\mathrm{y}$-ante todo- las perspectivas que se desprendieron del racionamiento científico del siglo XVIII.

\section{Bibliografía}

ACOSTA, Joseph de, Historia natural y moral de las Indias en que se tratan de las cosas notables del cielo, elementos, metales, plantas y animales dellas, ritos y ceremonias, leyes y gobiernos de los indios, México, Fondo de Cultura Económica, 2006.

Alberola RomÁ, Armando, «Agricultura, clima y superstición en la España del siglo XVIII: algunas reflexiones del padre Feijoo», 21-42, en Inmaculada Urzainqui y Rodrigo Olay Valdés (eds.), Con la razón y la experiencia. Feijoo 250 años después, Oviedo, Instituto Feijoo de Estudios del siglo XVIII/ Universidad de Oviedo/Ediciones Trea, 2016: 21-42.

ALDRETE, Bernardo, Del origen y principio de la lengua castellana o romance, que oí se usa en España, Madrid, por Melchor Sánchez, 1674.

ASSO Y DEL Río, Ignacio de, Discurso sobre la langosta y los medios de exterminarla, [S.l.], [s.n.], 1785. Disponible en: http://bdh-rd.bne.es/viewer. vm?id=0000108561\&page $=1$

BARCIA Y ZAMBRANA, José de, Despertador christiano de sermones doctrinales, sobre particulares asuntos, dispuesto para que se vuelva en su acuerdo el pecador y venza el peligroso letargo de sus culpas, animándose a la penitencia. Que después de las impresiones, en cinco, y en dos tomos, sale ahora en tres, con aplicación a adviento y cuaresma. Tomo tercero que con los otros dos dedico al santísimo padre Inocencio XI, pontífice máximo, siendo canónigo de la Santa Iglesia de Toledo, primada de las Españas, Cádiz, en casa de Christóbal de Requena, 1694. Disponible en: https://catalog.hathitrust.org/Record/009306357

BouZA, Fernando, Comunicación, conocimiento y memoria en la España de los siglos XVI y XVII, Salamanca, Seminario de Estudios Medievales y Renacentistas, 1999.

BouZA, Fernando, Corre manuscrito. Una historia cultural del siglo de Oro, Madrid, Marcial Pons, 2001. 
Bouza, Fernando, Papeles y opinión. Políticas de publicación en el siglo de Oro, Madrid, Consejo Superior de Investigaciones Científicas, 2008.

BOWLES, Guillermo, Introducción a la Historia Natural y a la Geografía Física de España, Madrid, en la Imprenta Real. Disponible en: http://bvpb.mcu.es/institutos/es/consulta/resultados_navegacion. cmd?busq_autoridadesbib=BVPB20090088504

BufFon, George Louis Leclerc, conde de, Espíritu del Conde de Buffon, Valladolid, por la viuda e hijos de Santander, 1798. Disponible en: http://bibliotecadigital. jcyl.es/es/consulta/registro.cmd?id=12961

BurgoA, Francisco de, Palestra historial de virtudes y ejemplares apostólicos fundada del celo de insignes héroes de la sagrada orden de predicadores en este nuevo mundo de la América en las Indias Occidentales, México, Editorial Porrúa, 1989 [1670].

BURNS, Kathryn, Durham/ London, Duke University Press, 2010.

CALVO, Thomas, "Ciencia, cultura y políticas ilustradas (Nueva España y otras partes)», en Clara García Ayluardo (coord.), Las reformas borbónicas, 17501808, México, Fondo de Cultura Económica et al, 2010: 83-130.

CAmPILlo y Cossío, José, Nuevo sistema de gobierno económico para la América: Con los males y daños que le causa el que hoy tiene, de los que participa copiosamente España; $y$ remedios universales para que la primera tenga considerables ventajas, y la segunda mayores intereses. Madrid, en la imprenta de Benito Cano, 1789. Disponible en: http://www.memoriachilena.cl/602/w3-article-9311.html CAMUfFO, Dario y ENZI, Silvia, «Locust Invasions and Climatic Factors from the Middle Ages to 1800», pp. 43-73, en Theorical and Applied Climatology, 43/1-2 (1991): 43-73. Disponible en: http://www.academia.edu/6693577/ Locust_Invasions_and_Climatic_Factors_from_the_Middle_Ages_to_1800 Cañizares Esguerra, Jorge, Católicos y puritanos en la colonización de América, Madrid, Fundación Jorge Juan/Marcial Pons Historia, 2008.

CONCEPCIÓn, Luis de la, Práctica de conjurar en que se contienen exorcismos y conjuros contra los malos espíritus de cualquiera modo existentes en los cuerpos humanos, así en mediación de supuesto, como de su inicua virtud por cualquier modo y manera de hechizos. Y contra langostas y otros animales nocivos, Madrid, [s.n.], 1721. Disponible en: http://bibliotecadigital.jcyl.es/es/catalogo_imagenes/grupo.cmd?path=1008310 
Coto, Tomás de y Acuña, René (ed.), Thesaurus Verboru[m]: Vocabulario de la lengua cakchikel u [el] guatemalteca, nuevamente hecho y recopilado con sumo estudio, trabajo y erudición. México, UNAM, 1983.

DARNTON, Robert, La gran matanza de gatos y otros episodios en la historia de la cultura francesa, México, Fondo de Cultura Económica, 1987.

Díaz del CASTILlo, Bernal, Historia verdadera de la conquista de Nueva España, México, Editorial Porrúa, 1960.

Die Maculet, Rosario y Alberola Romá, Armando, Jorge Juan Santacilia. De 'pequeño filósofo' a 'Newton español', Alicante, Edicions Locals, 2015.

FERnÁndez Baños, Cándida y Arias Simarro, Concepción, «Introducción. La ciencia mexicana en el siglo de las luces», en Elías Trabulse, Historia de la ciencia en México. Estudios y textos, siglo XVIII, México, Consejo Nacional de Ciencia y Tecnología/Fondo de Cultura Económica, 1985: 9-28.

FUENTES y GuZMÁN, Francisco de, Historia de Guatemala o Recordación florida, escrita en el siglo XVII..., Tomo I, Madrid, Luis Navarro Editor, 1882. Disponible en: http://bibliotecadigital.aecid.es/bibliodig/es/consulta/registro. cmd? id $=1077$

Füssel, Stephan, GASTGEBer, Christian y Fingernagel, Andreas, El libro de las biblias. Las biblias iluminadas más bellas de la Edad Media, Colonia, Taschen, 2016.

GAGE, Tomás, Los viajes de Tomás Gage a la Nueva España. Parte tercera: Guatemala. Segunda entrega, Guatemala, Editorial Artemis, 2000.

García Acosta, Virginia et al., Desastres agrícolas en México. Catálogo histórico. Tomo I. Épocas prehispánica y colonial (958-1822), México, Centro de Investigaciones y Estudios Superiores en Antropología Social/Fondo de Cultura Económica, 2003.

GARCÍA QUINTANILLA, Alejandra, «Saak'y el retorno del fin del mundo. Las plagas de langosta en las profecías del Katun 13 Ahau», en Ancient Mesoamerica, 16/2 (2005): 327-344. https://doi.org/10.1017/S0956536105050170

GÉRARD, André-Marie y Nordon GÉRARd, Andrée, Diccionario de la Biblia, Madrid, Anaya/Mario Munchnik, 1996.

GómEZ, Lidia, «La percepción de los fenómenos naturales como fuente de explicación de la vida social y política en los anales indios angelopolitanos, siglo XVII», en Eddy Stols, Werner ThOMAS y Johan VerberCKMOES (eds.)), Naturalia, Mirabilia \& Mostrosa en los imperios ibéricos: siglos XV-XIX, Leuven, Leuven University Press, 2006: 89-106. 
Grijalva, Juan de, Crónica de la orden de Nuestro Padre San Agustín en las provincias de la Nueva España en cuatro edades desde el año de 1533 hasta el de 1592, México, en el convento de Nuestro Padre San Agustín, con la imprenta de Juan Ruiz, 1624. Disponible en: http://bvpb.mcu.es/es/consulta/registro. cmd?id=397519

GRUZINSKI, Serge, «Las repercusiones de la Conquista: la experiencia novohispana», pp. 148-171, en Carmen BERNAND (ed.), Descubrimiento, conquista y colonización de América a quinientos años, México, Fondo de Cultura Económica, 1994: 148-171.

GrUZINSKI, Serge, El pensamiento mestizo, Barcelona, Ediciones Paidós, 2000.

HARRIS, Marvin, Bueno para comer. Enigmas de alimentación y cultura, Madrid, Alianza Editorial, 1989.

Jovellanos, Gaspar Melchor de, Informe de la Sociedad Económica de esta Corte al Real y Supremo Consejo de Castilla en el expediente de la Ley Agraria, extendido por su individuo de número el Señor Don Gaspar Melchor de Jovellanos, a nombre de la Junta encargada de su formación y con arreglo a sus opiniones, Madrid, en la imprenta de Sancha, 1795. Disponible en: http://fama2.us.es/ fde/informeDeLaSociedadEconomica.pdf

Jovellanos, Gaspar Melchor de y LinARES y PACHECO, Venceslao, Obras del excelentísimo señor don Gaspar Melchor de Jovellanos. Ilustradas con numerosas notas y dispuestas por orden de materias en un plan claro, vario y ameno, aumentadas además con un considerable caudal de escritos del autor, dignos de la luz pública e impresos ahora colectivamente por primera vez, con la vida de Jovellanos, retratos y viñetas, tomo VII, Barcelona, Imprenta de don Francisco Oliva, 1840.

Landa, Diego de, Relación de las cosas de Yucatán, México, P. Robredo, 1938.

LARRAZABAL, Antonio, Apuntamientos sobre la agricultura y comercio del reino de Guatemala, Nueva Guatemala, Impreso en la Oficina de don Manuel de Arévalo, 1811. Disponible en: https://archive.org/details/apuntamientossobrela00guat LÉvi-Strauss, Claude, Mitológicas. Lo crudo y lo cocido, México, Fondo de Cultura Económica, 1986.

LÉvi-Strauss, Claude, El pensamiento salvaje, México, Fondo de Cultura Económica, 1988.

LÓPEZ RuBiÑos, Alonso, Theatro de la verdad o apología por los exorcismos de las criaturas irracionales $y$ de todo género de plagas, y por la potestad que hay en la iglesia para conjurarlas. En respuesta de lo que contra este punto defiende el 
Maestro Feijoó en el tomo octavo y nuevamente en el último de su Theatro Crítico.

Madrid, en la imprenta del convento de dicha Orden, 1741. Disponible en: https://babel.hathitrust.org/cgi/pt?id=ucm.532077792x

LORA, Pablo de, Justicia para los animales. La ética más allá de la humanidad, Madrid, Alianza Editorial, 2013.

Mediz Bolio, Antonio, El libro del Chilam Balam de Chumayel, San José, Ediciones del Repertorio Americano, 1930. Disponible en: http://dgb.conaculta.gob.mx/ coleccion_sep/libro_pdf/42001049711.pdf

MEndieta, Jerónimo de, Historia eclesiástica indiana. Obra escrita a fines del siglo XVI por fray Gerónimo de Mendieta de la orden de San Francisco. La publica por primera vez Joaquín García Icazbalceta, México, Antigua librería, 1890.

MunCK, Thomas, Historia social de la Ilustración, Barcelona, Crítica, 2001.

PAQUETTE, Gabriel, «Carlos III: la ilustración entre España y Ultramar», en

Antonino de Francesco, Luigi Mascilli Migliorini y Raffaele Nocera (coords.), Entre Mediterráneo y Atlántico. Circulaciones, conexiones y miradas, 1756-1867, Santiago de Chile, Fondo de Cultura Económica, 2014: 73-92.

Pastoureau, Michel, El cerdo. Historia de un primo malquerido, Salamanca, Confluencias Editorial, 2015.

QUIÑONES, Juan, Tratado de las langostas muy útil y necesario, en que se tratan cosas de provecho y curiosidad para todos los que profesan letras divinas y humanas, y las mayores ciencias, Madrid, por Luis Sánchez Impresor, 1620. Disponible en: https://catalog.hathitrust.org/Record/009328318

QuirOz, Enriqueta, «Entre el humanismo y el mercantilismo: el bien común en el abasto de carne de ciudad de México, 1706-1716», Cuadernos de historia, 35 (2011): 35-59. http://dx.doi.org/10.4067/S0719-12432011000200002

REAL ACADEMIA ESPAÑOLA, Diccionario de la lengua castellana en que se explica el verdadero sentido de las voces, su naturaleza y calidad con las frases o modos de hablar, los proverbios y refranes y otras cosas convenientes al uso de la lengua, dedicado al Rey Nuestro Señor don Felipe V (que Dios guarde) a cuyas reales expensas se hace esta obra. Tomo Cuarto, que contiene las letras $G, H, I, J, K, L$, M, N y Ñ con privilegio..., Madrid, Herederos de Francisco del Hierro, 1734. Disponible en: http://bdh.bne.es/bnesearch/detalle/4199974

RECINOS, Adrián (ed., trad. y not.), Memorial de Solola. Anales de los cakchiqueles, México, Fondo de Cultura Económicas, 2006.

REMESAL, Antonio de, Historia de la provincia de San Vicente de Chiapa y Guatemala de la orden de nuestro glorioso padre Santo Domingo, escríbese justamente los 
principios de las demás provincias de esta religión de las Indias Occidentales y la Secular de la Gobernación de Guatemala. Madrid, en la imprenta de Francisco de Abarca y Angulo, año de 1619. Disponible en: https://archive.org/details/ historiadelaprov00reme

Rodríguez CAMPOMANES, Pedro, Discurso sobre el fomento de la industria popular, Madrid, en la Imprenta de don Antonio de Sancha, 1774. Disponible en: http://bvpb.mcu.es/es/consulta/registro.cmd?id=404351

SAHAGÚN, Bernardino de, Historia general de las cosas de Nueva España, escrita por fray Bernardino de Sahagún, franciscano, y fundada en la documentación en lengua mexicana recogida por los mismos naturales, México, Editorial Porrúa, 1992.

SistaCH, Xavier, Bandas, enjambres y devastación. Las plagas de langosta a través de la historia, Barcelona, Almuzara, 2007.

Terreros y PANDO, Esteban de, Diccionario castellano con las voces de ciencias y artes y sus correspondientes en las tres lenguas francesa, latina e italiana, tomo II, Madrid, en la imprenta de la viuda de Ibarra, hijos y compañía, 1786. Disponible en: http://bdh.bne.es/bnesearch/CompleteSearch.do?visor=\&text $=\&$ field l val $=\% 22$ Terreros $+y+$ Pando $\% 2 c+$ Esteban + de $\% 22 \&$ showYearItems $=\&$ field $1 O p=$ AND $\&$ numfield $s=1 \&$ exact $=$ on $\&$ textH $=\&$ advanced $=-$ true\&field $1=$ autor $\&$ completeText $=\&$ pageSize $=1 \&$ pageSizeAbrv=30\&pageNumber $=2$

TORQUemADA, Juan de, Primera parte de los veinte y uno libros rituales y monarquia indiana, con el origen y guerra de los indios occidentales, de sus poblaciones, descubrimiento, conquista, conversión y otras cosas maravillosas de la misma tierra distribuidos en tres, Madrid, en las Oficinas de Nicolás Rodríguez, 1723. Disponible en: http://bvpb.mcu.es/es/consulta/registro.cmd?id=406294

TRABULSE, Elías, «La colonia (1521-1810)», pp. 15-42, en Ruy PÉREZ TAMAYO (Compilador), Historia de la ciencia en México, México, Fondo de Cultura Económica / Consejo Nacional para la Cultura y las Artes, 2010.

VÁzQUez, Francisco, Crónica de la provincia del Santísimo Nombre de Jesús de Guatemala de la Orden de Nuestro Seráfico Padre San Francisco en el Reino de la Nueva España. Tomo tercero, Guatemala, Sociedad de Geografía e Historia, 1940 [1716]. Disponible en: https://archive.org/details/crnicadelaprov16compguat WHITE, Sam, The Climate of Rebellion in the Early Modern Ottoman Empire, New York, Cambridge University Press, 2011. 
Nociones, creencias e ideas sobre plagas de langosta en Guatemala y Nueva España, siglo XVIII

Ximénez. Pedro, Libro de conjuros de Ximenez contra todas tempestades de truenos, granizo, rayos y contra las langostas, Burgos, librería de Felipe Zuazo, 1730. Disponible en: https://bibliotecadigital.jcyl.es/es/consulta/registro. cmd?id $=7377$

ZePEDA Y ViVero, Juan Antonio, Agricultura metódica, acomodada a la práctica del país, con varias noticias acerca de la naturaleza, propagación y extinción de la langosta, Madrid, en la oficina de Benito Cano, 1791. Disponible en: http:// bdh-rd.bne.es/viewer.vm?id=0000092074\&page $=1$ 